\title{
Czapskiego i Odojewskiego lektura Guzików. Fragment recepcji wiersza Herberta
}

\author{
|Wiesław Ratajczak
Uniwersytet im. Adama Mickiewicza w Poznaniu
}

W poznańskim archiwum Włodzimierza Odojewskiego przechowywana jest interesująca wymiana listów dotycząca Guzików Zbigniewa Herberta. Autor powieści Zasypie wszystko, zawieje... (1973), której fragmenty dotyczą zbrodni katyńskiej, informował poetę o szczególnej lekturze jego wiersza w pokoju Józefa Czapskiego, w domu „Kultury” w Maisons-Laffitte Sędziwy malarz był przyjacielem obu korespondentów, którzy uznawali go też za świadka wydarzeń, będących w ich świadomości jednymi z najtragiczniejszych (a także najusilniej zakłamywanych) w najnowszej polskiej historii. We wrześniu 1939 roku Czapski został wzięty do sowieckiej niewoli, a zwolniony z niej w 1941 roku na mocy układu Sikorski-Majski, podjął się poszukiwania zaginionych w ZSRR oficerów polskich, o których nie wiedziano jeszcze, że stali się ofiarami zbrodni katyńskiej. Świadectwo tych doświadczeń zawarł w książkach Wspomnienia starobielskie (1944) i Na nieludzkiej ziemi (1948). To Czapskiemu Herbert zadedykował wiersz z wybitą w tytule datą sowieckiej agresji na Polskę i z finalną refleksją o „najtrudniejszym kunszcie - odpuszczaniu win" (Herbert 2008, 9). Odojewski natomiast „Józefowi Czapskiemu i innym jeńcom obozu Starobielsk I na przełomie 1939 i 1940 roku" (Odojewski 2009, 86) dedykował napisane w 1980 roku opowiadanie Pod murem. Jego bohaterem jest "chudy malarz”, więzień obozu urządzonego przez sowietów w dawnych klasztorze. Odkrywa on, że utracił zdolność widzenia świata, nie dosłownie, lecz w sensie malarskiego doświadczania widoków: „Obce miejsca są naprawdę obce i nie da się ich naprawdę oswoić i przeniknąć. Myśli, że widzi wszystko zewnętrznie, nie malarsko, że jego widzenie jest tylko podparte wewnętrznym nakazem, wysiłkiem woli, żeby widzieć, więc nie jest widzeniem prawdziwym" (Odojewski 2009, 89). Próbuje tę umiejętność odzyskać, ćwiczy się w przypominaniu historii francuskiego malarstwa, „zamyka, oczy, zaciska powieki, 
jakby miał nadzieję, że kiedy je na nowo rozewrze, spojrzy na świat inaczej, okiem oczyszczonym, kiedy je jednak rozwiera, nie zmienia się nic, jest zmierzch" (Odojewski 2009, 90). Ćwiczenie pamięci (między inny z pomocą czytanych dawniej stron powieści Marcela Prousta) w wywoływaniu obrazów dalekich od współczesnego koszmaru, wytrwałe próby uspokojenia przyniosły ostatecznie rezultat, ale moment olśnienia wiązał się z przeczuciem śmierci:

Patrzy na nich, widzi ich i - jakby miał ich oczy, jakby z miejsca, w którym stoją pod jabłonką, patrzył także na siebie samego - widzi jednocześnie swoją chudą, wysoką postać w za luźnym szynelu na ramionach obwisających jak załamane skrzydła starego ptaka, opartą teraz plecami o mur. Wydaje mu się, że na nich wszystkich (i na nim samym też) leży cień śmierci (Odojewski 2009, 101).

O tym, że cień śmierci ofiar zbrodni katyńskiej na trwale zaznaczył się w biografii Józefa Czapskiego, Odojewski pisał na początku datowanego 11 X 1990 r. listu do Herberta: „Kiedy jesteśmy razem, zawsze wędrujemy w naszych rozmowach na wschodnie rubieże, a potem w głąb Rosji", by omówić „wszystkie bóle, Syberie i Katynie”. Głośna lektura Guzików jest tej powracającej wielekroć rozmowy niezwyczajnym momentem, jakby skupieniem jej w jeden obraz i jedno wzruszenie. Niemal niewidomy Czapski (utrata fizycznego wzroku przez sędziwego malarza jest ważnym kontekstem wspomnianego przed chwilą opowiadania Odojewskiego) bezbłędnie wybrał z leżących na stole papierów maszynopis wiersza i poprosił o jego lekturę. Odojewski wspominał: „Przeczytałem cicho raz, potem głośno, powtarzając ostatnie dwie zwrotki jeszcze raz. Spłakaliśmy się. To musiał być szczególny widok. On prawie stuletni i ja, jak on mówi, „młodzik”, ale któremu też przecież stuknęło już sześć krzyżyków, we łzach”.

Nietrudno dostrzec związek tej sceny z listu pisarza z sytuacją wcześniej opisaną $\mathrm{w}$ jego powieściach. Jak w kopercie adresowanej do Czapskiego przychodzi wiersz Herberta o Katyniu ${ }^{1}$, tak w twórczości Odojewskiego początkiem drogi do miejsca zbrodni na polskich oficerach jest korespondencja. W Wyspie ocalenia (powieści o niezwykle długich i skomplikowanych losach, we fragmentach gotowej już w $1950 \mathrm{roku}$, a bez cenzorskich skreśleń opublikowanej na emigracji dopiero w latach 1972-1973) list nadany przez Czerwony Krzyż trafił do Katarzyny, przynosząc jej informację o śmierci Aleksego, jej męża. Jedna z postaci, senior rodu Czerestwieńskich, tak relacjonował treść zawiadomienia: „Znaleźli go w jednym z tych grobów masowych, o których niedawno tyle pisano w niemieckich gazetach. Zidentyfikowano już ciało. Zbrodnię bada Czerwony Krzyż, więc można wierzyć ich informacjom. Leżał tam wśród ciał tysięcy innych oficerów" (Odojewski 1990, 169). Czerestwieński, stary Rosjanin, który z bolszewickiej Rosji uciekł do Polski, zastrzegał: ,„To nie my. Nas już nie ma. Nie ma Rosjan. Jest tylko po nich wspomnienie. To Sowieci. Nie nasze sumienie

${ }^{1}$ W liście 27 VI 1990 pisał Herbert do Czapskiego: „Przesyłam Tobie wiersz pt. Guziki, który wyrósł z Twojej cichej inspiracji” (Czapscy, Herbertowie, 2017, 111). 
ten mord obciąży” (Odojewski 1990, 170). Odojewski wyraźnie nawiązywał w ten sposób do poglądów Józefa Mackiewicza, swego przyjaciela, pisarza również pochłoniętego sprawą katyńską. Mackiewicz wielekroć podkreślał różnicę między Rosją a nowym, rewolucyjnym, opartym na kłamstwie i zbrodni tworze politycznym, jaki wyłonił się z chaosu rewolucji.

We wstępie do jednego z wydań Wyspy ocalenia Tomasz Burek pisał o przełomowym charakterze doświadczenia katyńskiego w biografii Pawła, głównego bohatera tej powieści inicjacyjnej:

Wreszcie na te wszystkie wstrząsy, jakich w swym sercu i sumieniu doznaje młodociany bohater, czy to odkrywając rodzinny dramat, czy to ulegając pierwszy raz fali miłosnego oczarowania, na to wszystko, samo z siebie poplątane, niepojęte, nakłada się szok Katynia.

Powiadomienie z Czerwonego Krzyża o znalezieniu zwłok Aleksego Wojnowicza w jednym z grobów masowych ma w Wyspie ocalenia wiele sensów i wymiarów. Jest faktem węzłowym w dziejach powieściowego bohatera. Dopełnia jego inicjacji. Albowiem niweczy ostatnią przegrodę między ułudą wyobrażeń a niewyobrażalnym koszmarem zdarzeń, między (iluzorycznym) rajem „niewinności, prostoty i poezji” a czyhającą w głębokim cieniu otchłanią prawdy (Burek 1990, 9).

Katyń jest bez wątpienia faktem węzłowym także w życiu i twórczości Józefa Czapskiego oraz Włodzimierza Odojewskiego. Ponowienie tego doświadczenia za sprawą lektury Guzików wiąże się z skomplikowaniem znaczeń związków ciała i ziemi. Herbert pytał w wierszu:

Lecz jak zmartwychwstać mają ciałem

Przecież są lepką cząstką ziemi (Herbert 2008, 24)

Ciało wrzucone do masowego dołu śmierci, bez pogrzebowych obrzędów i bez znaku pamięci, ma zniknąć jako ostatnia pozostałość zbrodni, stać się nierozróżnialną cząstką ziemi. Proces zacierania, zabezpieczania i rozpoznawania śladów to powracający wątek twórczości Odojewskiego, a odnalezienie ciała, odróżnienie go od ziemi to imperatyw dla bliskich i dla wszystkich, którzy poczuwają się do duchowego związku z ofiarami. Nakazowi temu chciał być wierny Paweł w powieści Zasypie wszystko, zawieje... (1973), w dole śmierci szukający ciała przyrodniego brata, Aleksego:

I widząc rozgrzebany w ziemi, jak rana, dół, jak ślepiec potoczył się w tym kierunku (na nogach odmawiających mu już posłuszeństwa, zanim się był jeszcze poruszył) i zaczął schodzić w tę ludzką maź i gnilne opary, krzycząc: „Przecież jest! Znalazłem! Znajdę", aż jeden z mężczyzn w białym kitlu poderwał się od pobliskiego stołu i go powstrzymał, bo byłby w tym wszystkim na dnie ugrzązł, bo byłby w to runął (Odojewski 2006, 127).

W obrazie, który Paweł za wszelką cenę chciał zapamiętać, ważnym, wyrazistym i koncentrującym uwagę szczegółem są właśnie guziki, o których Odojewski i Czapski przeczytają w wierszu Herberta. Twarda materialność tych drobnych przedmiotów, banalnie praktycznych, a jednocześnie 
symbolicznych, bo ozdobionych godłem, przeciwstawia się siłom rozkładu i zamiarowi ukrycia zbrodni i pozbawienia godności jej ofiar:

utrwalał ten obraz w swej pamięci na zawsze: parometrowe złoża zwłok w polskich mundurach oficerskich z zachowanymi nieźle jeszcze guzikami i odznaczeniami, w ciężkich zimowych płaszczach, złoża zwłok zniszczonych w skomplikowanym procesie gnicia, a zarazem mumifikacji, zapewne dzięki zawartości piasku w glebie, potem z tej masy, z tej plątaniny wyróżnił poszczególne twarze tych, co leżeli zwróceni przodem ku górze (Odojewski 2006, 128).

Guzik będzie też w kopercie z rzeczami znalezionymi podczas ekshumacji i identyfikacji ciał. Bliscy Aleksego zobaczyli

złożoną na czworo stronnicę gazety rosyjskiej, parę monet jednozłotowych, strzęp książeczki wojskowej, na którym wyblakłym, pokrytym zaciekami i plamami pismem widniały wypisane Aleksego personalia, guzik z orzełkiem od munduru i sczerniałą, przeżartą korozją papierośnicę (Odojewski 2006, 134).

W tym fragmencie powieści Odojewskiego przekreślone zostały, wspomniane później przez Herberta, logika związków ciała i „lepkiej cząstki ziemi" oraz porządek rozkładu i unieważniania. Wprost o tym mowa w homilii, głoszonej przez kapłana podczas pogrzebu oficerów, którzy (jak najpierw guziki, by przywołać obraz z wiersza) z "głębin wyszli na powierzchnię” i z ofiar stali się także „świadkami zbrodni”:

Nie zniknęli, tylko po prostu przenieśli się w utysiąckrotnione życie. W pamięć najbliższych, w trwałą pamięć naszego narodu, a także w pamięć tego narodu, który zadaje równie łatwo męczarnię i śmierć innym, jak i sobie samemu. (...) Nie przywaleni ziemią na zawsze. Ale od niej wolni, z jej czarnego wnętrza powstający, by wejść i pozostać w każdym z nas" (Odojewski 2006, 136).

Te ścisłe zbieżności między scenami z powieści Odojewskiego i wiersza Herberta można, oczywiście, uznać za przejaw obecności w twórczości ich obu topiki katyńskiej, występującej w wielu tekstach tej problematyce poświęconych. Jednak fakt wspólnej, pisarza i Czapskiego, lektury Guzików ustanawia szczególny związek cytowanych fragmentów powieściowych $\mathrm{z}$ wierszem.

Na list Odojewskiego Herbert odpowiedział korespondencją z Paryża, datowaną $13 \mathrm{~V}$ 1991. Przechowany również w poznańskim archiwum Odojewskiego rękopis powstał na papierze firmowym Mishkenot Sha'ananim, pensjonatu dla odwiedzających Izrael słynnych pisarzy, artystów i muzyków. O swej izraelskiej podróży Herbert w liście krótko, z sarkazmem wspominał: „dostałem nagrodę Jerozolimy, więc trzeba było odpowiadać na pytania, dlaczego Polacy są antysemitami i różne podobne przyjemności!!!”

Do Guzików wprost się ich autor nie odniósł, wspomniał jednak ciepło o „Józiu Czapskim”. Pisał Herbert: „Wciąż żyje, ja telefonuję raczej rzadko, raz tylko króciutko rozmawiałem, był cudowny (...). To cudowny człowiek i bardzo się męczy". 
O jednym jeszcze, pośrednio z lekturą Guzików, fragmencie listu warto wspomnieć. Krótka w nim wzmianka dotyczy audycji Odojewskiego o pewnym znanym niemieckim pisarzu:

„Słyszałem w grudniu u [biegłego] r[oku] Twoje wspomnienie o Horście Binku², który był także moim przyjacielem - wspomnienie tak piękne, że się popłakałem.

No pomyśl, dobrzy ludzie odchodzą, a źli twardo ostają i jeszcze brużdżą i broniąswoich zasranych stołków. Dochodzę do wniosku, że to niesprawiedliwość".

Mowa tu o audycji z cyklu "Czasy zwykłe, czasy ciekawe”, emitowanej w Radiu Wolna Europa 16 XII 1990 roku. Wspominając Horsta Bienka, Odojewskiego nadmienił także o literaturze Kresów jako wspólnym fenomenie kultury polskiej i niemieckiej:

Mówią one obie o świecie, który już nie istnieje, pogranicznym świecie mieszanym narodowościowo i religijnie, zróżnicowanym społecznie i obyczajowo, który raz na zawsze uległ zagładzie, pogrążył się w ogniu i popiele wojny, i pozostał jedynie w pamięci (Odojewski, 1990).

Żadnego z wybitnych przedstawicieli niemieckiej literatury kresowej nie można - podkreślał autor felietonu - pomawiać o rewanżyzm czy rewizjonizm. Odojewski przypomniał, że obok Śląska, jako kraju dzieciństwa i wczesnej młodości, drugim wielkim tematem Bienka są zbrodnie sowieckie. W roku 1951 został aresztowany przez władze komunistycznych Niemiec, w 1951 skazany na 25 lat obozu koncentracyjnego, w czerwcu tegoż roku wydany w ręce sowieckie. W Workucie zetknął się więzionymi tam Polakami. Odojewskiemu jego twórczość była bliska ze względu na wspólnotę tematów, kresowego i sowieckiego, a także z powodu ustawicznych starań o pogodzenie narodów Europy Środkowej.

I o jeszcze jednym drobnym, wspólnym wątku obu listów warto wspomnieć: płaczu, o którym w zaufaniu mężczyźni wzajem się informują. W twórczości Odojewskiego niepowstrzymany odruch wzruszenia jest częstym, niezbywalnym elementem, dość przypomnieć finał opowiadania Grzech z tomu Jedźmy, wracajmy... (1993). Jego tematem jest relacja między synem, który w powojennej rzeczywistości chce się uczyć, urządzić w życiu, i ojcem - żołnierzem antykomunistycznego podziemia, niezłomnym, a w oczach syna - przegranym. Ulgę, rozwiązanie, wyznanie i oczyszczenie przynosi scena płaczu, gdy wobec zmarłego rodzica syn zdobywa się na płacz i proste wyznanie miłości. A Herbert o „bezradnym płaczu” wspomina przecież w wierszu Do Marka Aurelego (Herbert 2008, 44), dedykowanym mistrzowi, prof. Henrykowi Elzenbergowi.

Obok dwóch omówionych tu listów w archiwum przechowywany jest również odpis wiersza Herberta sporządzony przez Odojewskiego.

Korespondencja w sprawie Guzików jest drobiazgiem, wartym odnotowania na marginesach biografii trzech wybitnych twórców: Józefa

${ }^{2}$ Powinno być: Bienku 
Czapskiego, Zbigniewa Herberta i Włodzimierza Odojewskiego. To ledwie kilka zdań, lecz odnoszą się one do spraw w ich osobistym doświadczeniu i w ich dziele szczególnie ważnych.

\section{Bibliografia:}

Burek Tomasz, 1990, Przedmowa, w: Odojewski W., Wyspa ocalenia, Białystok. Herbert Zbigniew, 2008, 89 wierszy, Kraków.

Józef i Maria Czapscy, Katarzyna i Zbigniew Herbertowie, 2017, Korespondencja, Strzałka J. (odczytał i przypisami opatrzył), Warszawa.

Odojewski Włodzimierz, 1990, Czasy zwykłe, czasy niezwykłe, cz. 18 [audycja radiowa], Monachium, https://www.polskieradio.pl/68/2461/ Audio/312117,Czasy-zwykle-czasy-ciekawe-cz018 (dostęp: 29.06.2018).

Odojewski Włodzimierz, 1990, Wyspa ocalenia, Białystok.

Odojewski Włodzimierz, 2006, Zasypie wszystko, zawieje..., Warszawa.

Odojewski Włodzimierz, 2009, Pod murem, w: W stepie, ostach i burzanie i inne opowiadania, Warszawa.

\section{O Autorze:}

Wiesław Ratajczak - historyk literatury, prof. UAM, w latach 2012-2016 kierownik Pracowni Badań nad Tradycją Europejską w Instytucie Filologii Polskiej. Badacz kultury polskiej drugiej połowy XIX wieku. Wykłada teorię i historię kultury w Studium Fotografii przy Uniwersytecie Artystycznym w Poznaniu. Prezes Oddziału Poznańskiego Towarzystwa Literackiego im. Adama Mickiewicza. Autor książek: Teodor Tomasz Jeż (Zygmunt Miłkowski) i wiek XIX (Poznań 2006), Słownik motywów literackich (Poznań 2006), Literatura polska XIX wieku (Poznań 2008), Conrad i koniec epoki żaglowców (Poznań 2010). Współredaktor tomów zbiorowych: Poznań Czerwiec 56. Sens pamięci (Poznań 2006), Europejskość i rodzimość. Horyzonty twórczości Józefa Ignacego Kraszewskiego (Poznań 2006), Cóż wiesz o pięknem? Szkice o literaturze, filmie, muzyce i teatrze (Poznań 2007), Norwid - artysta (Poznań 2010), W kręgu młodokonserwatyzmu warszawskiego 1876-1918 (Bydgoszcz 2015) i in. Autor artykułów poświęconych polskiej prozie drugiej połowy XIX wieku, literackiej symbolice religijnej, stereotypom i mitom narodowym $\mathrm{w}$ powieściach, a także prac o charakterze metodycznym oraz recenzji literackich i filmowych. 